\title{
Brockite in wallrock metasomatites of the Safyanovskoe copper-sulphide deposit (Middle Urals)
}

\author{
Elena Industrovna SOROKA*, \\ Lyubov' Vladimirovna LEONOVA*, \\ Mikhail Egorovich PRITCHIN
}

The Zavaritsky Institute of Geology and Geochemistry of the Ural Branch of RAS, Ekaterinburg, Russia

\section{Abstract}

The relevance of the work is due to the need to study ore copper-sulphide deposits in the Urals.

Purpose of the work: description of accessory brockite in metasomatites of the Safyanovskoe copper-sulphide deposit. Research methodology: the chemical composition of minerals was determined using the Jeol JSM-6390LV scanning electron microscope with an INCA Energy 450 X-Max 80 energy dispersive attachment from Oxford Instruments (Institute of Geology and Geochemistry of the Ural Branch of the Russian Academy of Sciences, Ekaterinburg).

Results and conclusions. For the first time for the Safyanovskoe copper-sulphide deposit (Middle Urals), an aqueous rare earth phosphate of calcium and thorium, brockite, has been determined; it belongs to the group of rhabdophane $(\mathrm{Ca}, \mathrm{Th}, \mathrm{REE})[\mathrm{PO}]_{4} \cdot \mathrm{H}_{2} \mathrm{O}$. The mineral is rare for the Urals and was described earlier in granite pegmatites of the Middle and South Urals, as well as in dikes of metaplagiogranites of the Bazhenov ophiolite complex. Brockite was found in the rocky metasomatites of the Safyanovskoe copper-sulphide deposit after crystalline lithoclastic tuff (tuffaceous sandstone) of acid composition. The main mass of the rock consists of quartz, kaolinite (sericite), carbonates (dolomite, Fe-magnesite) with rare inclusions of pyrite. Brockite is found in the dolomite-quartz matrix of the sample in intergrowths with REE-goyazite - strontium aluminophosphate. It is assumed for the Safyanovskoe copper-sulphide deposit that an alumina association with an ore mineral association and rare earth minerals, in particular, REE-alumophosphates and phosphates, will form closely at the same time as the temperature drops and the redox conditions of the mineral formation environment change.

Keywords: brockite, goyazite, metasomatites, Safyanovskoe copper-sulphide deposit, Middle Urals.

\section{Introduction}

The Safyanovskoe copper-sulphide deposit is located 10 $\mathrm{km}$ northeast of the town of Rezh (Sverdlovsk region) and is confined to the southern part of the Rezhevskaya structural-formation zone. Its structure involves volcanic, volcanic-sedimentary and carbonate-terrigenous complexes of the Devonian-Lower Carboniferous age [1] (Fig. 1). The ore-bearing strata of the deposit has a thickness of about 500 $\mathrm{m}$. Massive pyrite, copper-zinc and copper vein-disseminated ores are localized in metasomatically altered acidic volcanites (rhyolites, rhyodacites) and are mined in a quarry and a mine. Metasomatites occupy a regular position relative to ore bodies [2]. At the contact with ore bodies, pyrite-chalcopyrite-chlorite-quartz and alunite (pyrophyllite) -kaolinite-sericite-pyrite-quartz metasomatites are developed [3].

Objects and methods of research

In a sample of wall rock metasomatites (sample 3/17) selected in 2017 in the face of a quarry at a depth of $200 \mathrm{~m}$ at the contact with massive pyrite-sphalerite-chalcopyrite ore, an aqueous rare-earth phosphate of calcium and thorium - brockite was discovered, which belongs to the group of rhabdophane $(\mathrm{Ca}, \mathrm{Th}, \mathrm{REE})[\mathrm{PO}]_{4} \times \mathrm{H}_{2} \mathrm{O}$. This is the first find in the rocks of the Safyanovskoe deposit. Earlier, in metasomatites after rhyodacite (sample 2/17), a rare-earth strontium aluminum phosphate
- goyazite was described [4]. Goyazite, together with brockite, was also found in sample no. 3/17. For the first time at the Safyanovskoe deposit, goyazite was described in association with barite veins in wall-rock sericite-pyrite-quartz metasomatites [5], and rare-earth goyazite in contact with Fe-magnesite was described in altered felsic volcanics [6].

The rock in sample $3 / 17$ is metasomatite of felsic crystalline-lithoclastic tuff (tuffaceous sandstone). A green-gray sample contains fragments of an irregular shape with rounded edges up to $3 \mathrm{~mm}$ in size with a recrystallized main mass of kaolinite (sericite) -carbonate-quartz composition (Fig. 2, a, b). Cement is composed of kaolinite, quartz, carbonate with rare pyrite crystals. The texture of the main mass is spotty and associated with the formation of monomineralic segregations of microquartz aggregate; the structure is fine-grained lepidogranoblastic. Carbonates are represented by ferruginous dolomite and amoeba-like grains of ferruginous magnesite up to $1 \mathrm{~mm}$ in size (Fig. 2, a). Veins and fractures up to 3-5 mm thick, filled with pale yellow ferruginous magnesite with a distinct zonal structure. Brockite is found in a dolomite-quartz rock matrix in intergrowths with goyazite (Fig. 3).

The studies of goyazite and brockite were carried out using the JSM-6390LV (JEOL) scanning electron microscope with

\footnotetext{
凹soroka@igg.uran.ru

https://orcid.org/0000-0003-1360-6274

"Ivleonova@yandex.ru
} 

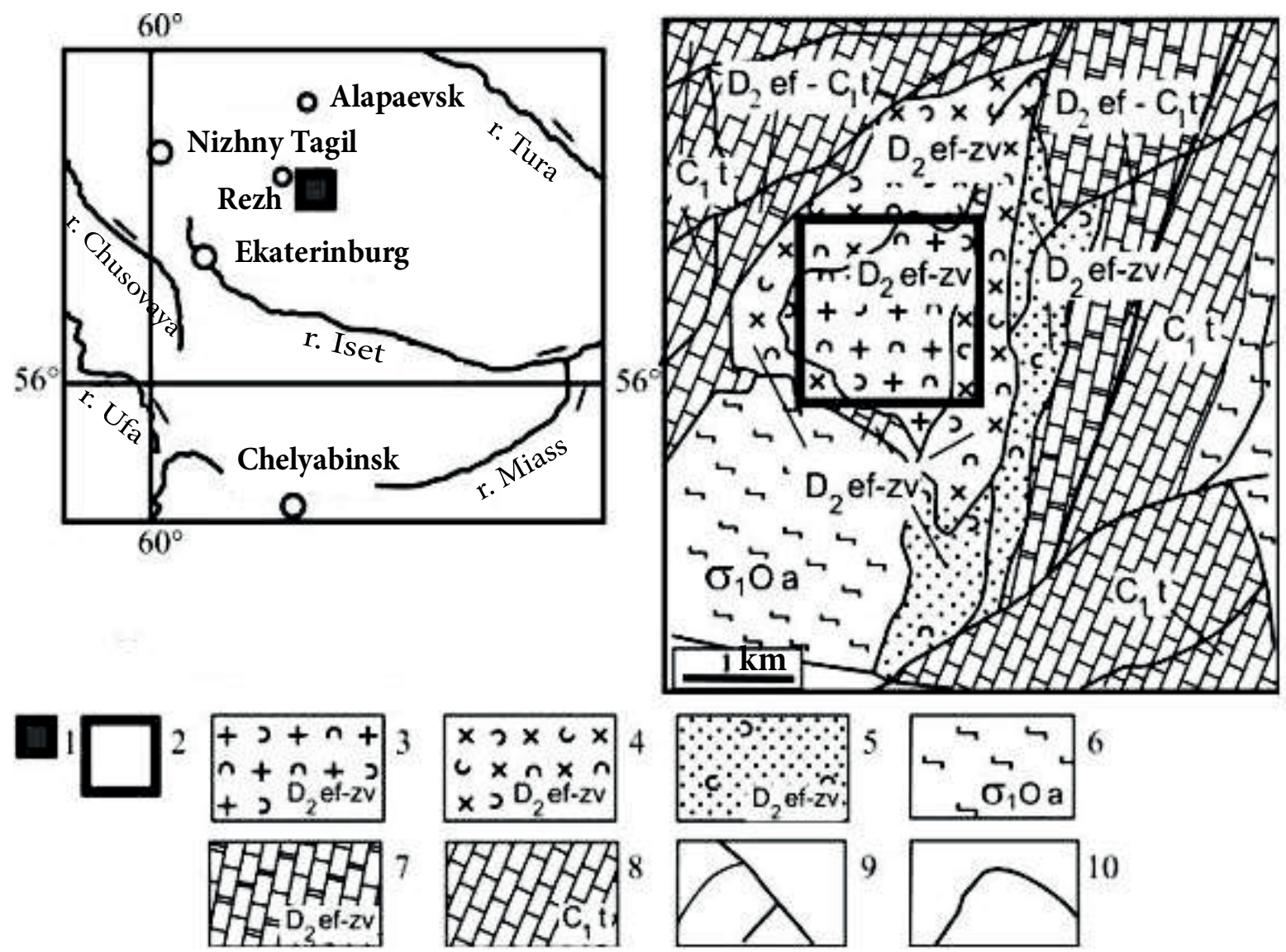

Figure 1. Areal map and geological diagram of the Safyanovskiy ore field. 1 - Safyanovskoe ore field; 2 - Safyanovsky quarry; 3 - acidic tuffs with interlayers of carbonaceous-siliceous rocks; 4 - tuffs, volcanic-sedimentary rocks with interlayers of limestone; 5 - volcanogenic-sedimentary rocks, sandstones, silty sandstones; 6 - serpentinites; 7 - marbled limestone; 8 - limestone; 9 - tectonic boundaries, faults; 10 - geological boundaries.

Рисунок 1. Обзорная карта и геологическая схема Сафьяновского рудного поля: 1 - Сафьяновское рудное поле; 2 - Сафьяновский карьер; 3 - туфы кислого состава с прослоями углеродисто-кремнистых пород; 4 - тусы, вулканогенно-осадочные породы с прослоямии известняков; 5 - вулканогенно-осадочные породы, песчаники, алевропесчаники; 6 - серпентиниты; 7 - мраморизованные известняки; 8 - известняки; 9 - тектонические границы, разрывные нарушения; 10 - геологические границы.
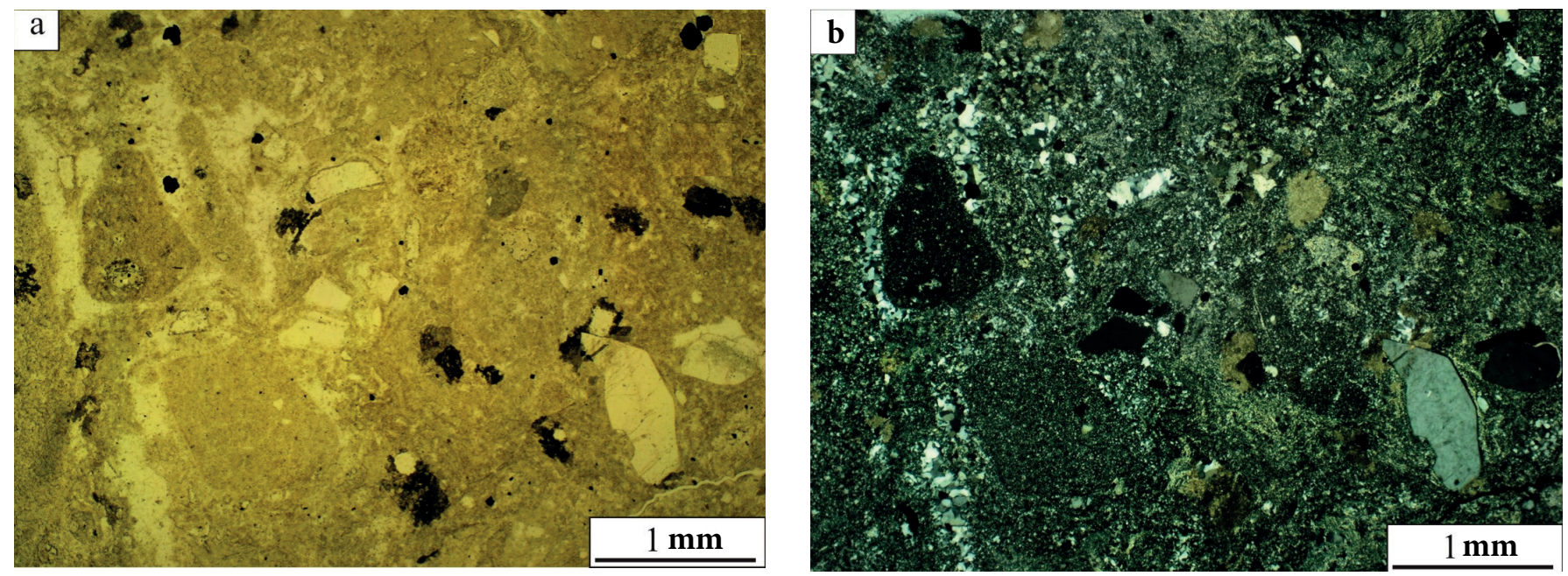

Figure 2. Photo of a transparent thin section of wallrock metasomatite on crystalline-clastic tuff (tuffaceous sandstone) of acid composition (sample 3/17) of the Safyanovskiy copper-sulphide deposit. a - without an analyzer; b - with an analyzer.

Рисунок 2. Фото прозрачного шлифа околорудного метасоматита по кристаллолито-кластическому туфу (туфопесчанику) кислого состава (обр. 3/17) Сафьяновского медноколчеданного месторождения: а - без анализатора; б - с анализатором. 


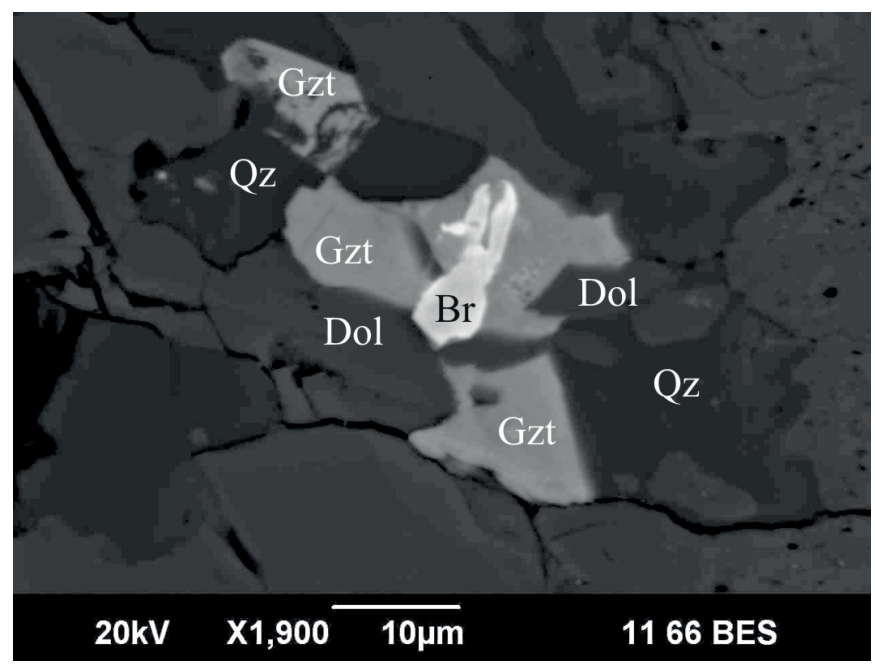

Figure 3. Brockite and goyazite in metasomatite matrix for crystalline-lithoclastic tuff. Gzt - goyazite, $\mathrm{Br}$ - brockite, Dol - dolomite, Qz - quartz. Photo in BSE mode, scanning electron microscope JSM-6390LV, IGG UB RAS, operator L. V. Leonova.

Рисунок 3. Броккит и гояцит в матрице метасоматита по кристаллолитокластическому туфрy. Gzt - гояцит, $\mathrm{Br}$ - броккит, Dol - доломит, Qz - кварц. Фото в BSE-режиме, сканирующий электронный микроскоп JSM-6390LV, ИГГ УрО РАН, оператор Л. В. Леонова. an INCA Energy 450 X-max 80 EDS spectrometer (laboratory of the FKhMI Institute of Geology and Geochemistry, Ural Branch of the Russian Academy of Sciences, Ekaterinburg). Data is shown in table.

Results and discussion

Brockite is quite rare in the Urals. It is found in the granite pegmatites of the Ilmen Mountains in the form of pseudomorphs based on xenotime crystals [7], as well as in the pegmatites of the northern part of the Aduy granite massif $[8,9]$ and in the Beregovaya vein within the Zenkovskiy granite massif [10]. In addition, it has been described within the Bazhenov ophiolite complex in plagiogranite dikes [11]. There it is confined to the clusters of monazite [12], overgrowing its crystals. At the Safyanovskoe deposit, monazite was found in a sample of sericitized brecciated rock (sample 78/01) [13] containing vein-disseminated copper-zinc ores represented by sphalerite, chalcopyrite, pyrite, and galena. Monazite in the form of small isometric crystals is confined to the segregations of sericite and galena along cracks and is represented by the cerium variety (Table).

The formation of brockite in plagiogranite dikes of the Bazhenov ophiolite complex is associated with low-temperature metamorphic processes of the prenite-pumpellite facies, which, according to the authors of [11], completely transformed the

Chemical composition of REE minerals in the wallrock of the Safyanovskoe copper pyrite deposit, wt\%.

Химический состав Р3Э минералов в околорудных породах Сафьяновского медноколчеданного месторождения, мас.\%

\begin{tabular}{|c|c|c|c|c|c|c|}
\hline \multirow[b]{2}{*}{ oxides } & \multicolumn{6}{|c|}{ REE minerals } \\
\hline & $\begin{array}{c}\text { Goyazite, } \\
\text { sample } 22 / 01\end{array}$ & $\begin{array}{c}\text { Monazite, } \\
\text { sample } 78 / 01\end{array}$ & $\begin{array}{c}\text { Goyazite, } \\
\text { sample 48/2-1 }\end{array}$ & $\begin{array}{c}\text { Goyazite, } \\
\text { sample } 3 / 17\end{array}$ & $\begin{array}{c}\text { Brockite, sample } \\
\qquad 3 / 17\end{array}$ & $\begin{array}{c}\text { Brockite, sample } \\
\qquad 3 / 17\end{array}$ \\
\hline $\mathrm{P}_{2} \mathrm{O}_{5}$ & 25.64 & 21.91 & 28.22 & 26.09 & 25.52 & 25.48 \\
\hline $\mathrm{SO}_{3}$ & 0.75 & $\mathrm{~N} / \mathrm{D}$ & 0.92 & - & - & - \\
\hline $\mathrm{ThO}_{2}$ & - & - & - & - & 1.49 & 1.08 \\
\hline $\mathrm{UO}_{2}$ & - & - & - & - & 0.52 & - \\
\hline $\mathrm{SiO}_{2}$ & 1.97 & 12.27 & $N / D$ & - & - & 0.31 \\
\hline $\mathrm{Al}_{2} \mathrm{O}_{3}$ & 29.84 & 3.69 & 28.51 & 24.58 & - & - \\
\hline $\mathrm{La}_{2} \mathrm{O}_{3}$ & 1.77 & 13.99 & 0.59 & 3.11 & 9.12 & 8.22 \\
\hline $\mathrm{Ce}_{2} \mathrm{O}_{3}$ & 3.27 & 23.88 & 1.51 & 6.20 & 22.56 & 21.53 \\
\hline $\mathrm{Pr}_{2} \mathrm{O}_{3}$ & $\mathrm{~N} / \mathrm{D}$ & 1.22 & - & - & 2.60 & 2.85 \\
\hline $\mathrm{Nd}_{2} \mathrm{O}_{3}$ & 1.51 & 9.99 & - & 3.44 & 14.76 & 15.67 \\
\hline $\mathrm{Sm}_{2} \mathrm{O}_{3}$ & $\mathrm{~N} / \mathrm{D}$ & 0.88 & - & - & 2.64 & 3.11 \\
\hline $\mathrm{Gd}_{2} \mathrm{O}_{3}$ & $\mathrm{~N} / \mathrm{D}$ & 1.17 & - & - & 1.81 & 2.14 \\
\hline $\mathrm{Fe}_{2} \mathrm{O}_{3}$ & 0.44 & $N / D$ & $N / D$ & - & - & - \\
\hline $\mathrm{FeO}$ & $\mathrm{N} / \mathrm{D}$ & $\mathrm{N} / \mathrm{D}$ & 0.49 & 0.55 & - & - \\
\hline $\mathrm{CaO}$ & $\mathrm{N} / \mathrm{D}$ & 0.61 & $\mathrm{~N} / \mathrm{D}$ & 0.71 & 1.10 & 1.29 \\
\hline $\mathrm{SrO}$ & 13.58 & $N / D$ & 19.13 & 9.80 & 1.96 & 1.77 \\
\hline $\mathrm{BaO}$ & 2.43 & $N / D$ & 1.55 & - & - & - \\
\hline $\mathrm{Na}_{2} \mathrm{O}$ & N/D & $N / D$ & 0.04 & - & - & - \\
\hline $\mathrm{K}_{2} \mathrm{O}$ & N/D & 0.84 & - & - & - & - \\
\hline Total & 81.20 & 90.45 & 80.96 & 74.48 & 84.07 & 83.45 \\
\hline
\end{tabular}

Note: N/D - element not detected; dash - element not determined.

Примечание: н. о. - элемент не обнаружен; прочерк - элемент не определялся. 
rock matrix. The formation of brockite at the Safyanovskoe deposit, as well as of rare earth goyazite, is probably associated with low-temperature metasomatism, which transformed felsic volcanics and tuffs that host pyrite mineralization. It should be noted that zones with a high alumina content (up to $28 \mathrm{wt} . \%$ $\mathrm{Al}_{2} \mathrm{O}_{3}$ ), in which high-alumina minerals such as alunite, kaolinite, pyrophyllite, are identified in the near-ore metasomatites of the Safyanovskoe deposit [3]. Our studies confirm that occurrence of rare earth minerals, in particular, goyazite, are often associated with them. At alunite, porphyry copper, and epithermal gold deposits, phosphorus-aluminum sulfates and arsenates with impurities of rare earths are found in associations with luzonite and enargite $[14,15]$, which is also true for the Safyanovskoe deposit $[2,3]$.

Together with brockite and goyazite in sample no. 3/17, there are also newly formed carbonates: Fe-dolomite, Fe-magnesite. Earlier studies have shown that magnesite mineralization in the wall rocks of the Safyanovskoe deposit is a derivative of an ore-bearing solution [16]. The mineral formation temperature did not exceed $250^{\circ} \mathrm{C}$. Siderite and magnesite are associated with ore minerals (pyrite, sphalerite), as well as with barite, kaolinite, quartz, hydromica, i. e. belong to the zone of development of kaolinite- (alunite) -sericite-pyrite-quartz metasomatites. Magnesite mineralization with Fe-magnesite belongs to the zone of carbonate-kaolinite-hydrosericite-chlorite-quartz metasomatites [16]. According to [3], alunite-sericite-pyrite metasomatites were formed under reducing conditions, at $\log \mathrm{fO}_{2}=-38$ and $\mathrm{pH}$ about 2.8, the kaolinite-alunite-sericite-quartz association was formed at a higher $\log \mathrm{fO}_{2}$ value, and $\mathrm{pH}$ - closer to 5.2 , the kaolinite-sericite-chlorite-carbonate-quartz association was formed under near-neutral conditions at a higher $\log \mathrm{fO}_{2}$ value.

\section{Conclusion}

For the first time for the Safyanovskoe copper-sulphide deposit (Middle Urals), an aqueous rare earth phosphate of calcium and thorium, brockite, has been determined; it belongs to the group of rhabdophane (Ca,Th,REE) $[\mathrm{PO}]_{4} \times \mathrm{H}_{2} \mathrm{O}$, It is assumed for the Safyanovskiy copper-sulphide deposit that an alumina association with an ore mineral association and rare earth minerals, in particular, REE-alumophosphates and phosphates, will form closely at the same time as the temperature drops and the redox conditions of the mineral formation environment change.

This work was carried out within the framework of the state assignment of the Institute of Geology and Geochemistry of the Ural branch of the Russian Academy of Sciences (state registration no. AAAA-A18-118052590028-9).

\section{REFERENCES}

1. Yazeva R. G., Moloshag V. P., Bochkarev V. V. 1992, Geologiya Saf'yanovskogo kolchedannogo mestorozhdeniya (Sredniy Ural) [Geology of the Safyanovskiy sulphide deposit (Middle Urals). Ekaterinburg, $70 \mathrm{p}$.

2. Grabezhev A. I., Moloshag V. P., Sotnikov V. I. 2001, Metasomatic halo of the Safyanovskiy Zn-Cu-pyrite deposit, Middle Urals. Petrologiya [Petrology], no. 3, pp. 294-312. (In Russ.)

3. Soroka E. I., Moloshag V. P., Leonova L. V., Galeev A. A. 2009, New data on hydrothermally altered rocks of the Safyanovskiy sulphide deposit (Middle Urals). Uchenye Zapiski Kazanskogo Universiteta (Proceedings of Kazan University), book 1, vol. 151, pp. 235-247. (In Russ.)

4. Soroka E. I., Leonova L. V., Pritchin M. E. 2019, REE-goyazite in the wallrock of the Safyanovskiy copper-sulphide deposit (Middle Urals, Russia). Ural Mineralogical School-2019. Proceedings of the youth scientific conference. Ekaterinburg, pp. 160-162.

5. Moloshag V. P., Soroka E. I., Filippov V. N. 2006, Strontium aluminum phosphate in the rocks of the Safyanovskiy sulphide deposit (Middle Urals). Theory, history, philosophy and practice of mineralogy. Materials of the international Symposium. Syktyvkar, pp. $192-193$.

6. Pritchin M. E., Soroka E. I., Moloshag V. P., Zamyatin D. A. 2014, Finds of goyazite in metasomatites of the Safyanovskiy copper-sulphide deposit. Ural Mineralogical School-2014. Proceedings of the youth scientific conference. Ekaterinburg, pp. 213-216.

7. Popov V. A., Kobyashev Yu. S. 1995, Finds of astrophyllite, brockite and mottramite in the Ilmen mountains. Ural mineralogical collection. Miass, no. 5, pp. 190-196.

8. Gubin V. A., Khiller V. V. 2012, Accessory brockite from pegmatites of the northeastern edge of the Aduy granite massif (Middle Urals). Vestnik Ural'skogo otdeleniya RMO [Bulletin of the Ural branch of the Russian Mineralogical Society], pp. 40-42. (In Russ.)

9. Popova V. I., Gubin V. A., Churin E. I., Kotlyarov V. A., Khiller V. V. 2013, Rare metal mineralization of granite pegmatites of the Rezhevsky region in the Middle Urals. Zapiski RMO [Proceedings of the Russian Mineralogical Society], part 142, no. 1, pp. 23-38. (In Russ.)

10. Popova V. I., Churin E. I., Blinov I. A., Gubin V. A. 2012, Fergusonite- (Y) and products of its alteration in granite pegmatite from the vein of the Beregovaya Zenkovsky massif in the Urals. Novyye dannyye o mineralakh [New data about minerals], issue 47, pp. 47-55. (In Russ.)

11. Erokhin Yu. V., Khiller V. V. 2018, On the discovery of brockite in dikes of plagiogranite of the Bazhenov ophiolite complex (Middle Urals). Yearbook-2017. Trudy Instituta geologii i geokhimii im. akad. A.N. Zavaritskogo [Proceedings of the Institute of Geology and Geochemistry named after A. N. Zavaritsky], issue 165, pp. 183-185. (In Russ.)

12. Erokhin Yu. V., Khiller V. V., Ivanov K. S. 2018, Early Silurian age of dikes of plagiogranite from the Bazhenovskiy ophiolite complex, Middle Urals (according to Th-U-Pb-dating of monazite). Vestnik voronezhskogo gosudarstvennogo universiteta [Proceedings of Voronezh State University]. Series: Geology, no. 3, pp. 17-21. (In Russ.)

13. Soroka E. I., Moloshag V. P., Leonova L. V., Filippov V. N. 2009, REE-mineralization in the wallrock of the Safyanovskiy copper-sulphide deposit (Middle Urals). Tenth all-Russian scientific readings in memory of V. O. Polyakov. Miass, pp. 30-35.

14. Deyell C. L., Rye R. O., Landis G. P., Bissig T. 2005, Alunite and the role of magmatic fluids in Tambo high-sulfidation deposit, EL Indio-Pascua belt, Chile. Chemical Geology, vol. 215, no. 1, pp. 185-218. https://doi.org/10.1016/j.chemgeo.2004.06.038

15. Dill H. G. 2001, The geology of aluminium phosphates and sulphates of the alunite group minerals: a review. Earth Science Reviews, vol. 53, pp. 35-93. https://doi.org/10.1016/S0012-8252(00)00035-0

16. Soroka E. I., Pritchin M. E., Lyutoev V. P., Galakhova O. L. 2016, Magnesite mineralization of the wallrock of the Safyanovskiy copper-sulphide deposit (Middle Urals). Zapiski RMO [Proceedings of the Russian Mineralogical Society], no. 2, pp. 96-109. (In Russ.) 


\title{
Броккит в околорудных метасоматитах Сасьяновского медноколчеданного месторожления (Средний Ураи)
}

\author{
Елена Индустровна СОРОКА*, \\ Любовь Владимировна ЛЕОНОВА \\ Михаил Егорович ПРИТЧИН
}

Институт геологии и геохимии им. акад. А. Н. Заварицкого УрО РАН, Екатеринбург, Россия

Аннотация

Актуальность работь обусловлена необходимостью изучения рудных медноколчеданных месторождений Урала.

Цель работь: описание находки акцессорного броккита в метасоматитах Сафьяновского медноколчеданного месторождения.

Методология исследования: химический состав минералов установлен с помощью сканирующего электронного микроскопа JSM-6390LV фирмы Jeol с энергодисперсионной приставкой INCA Energy 450 X-Max 80 фирмы Oxford Instruments (ИГГ УрО РАН, г. Екатеринбург).

Результаты и выводы. Впервые для Сафьяновского медноколчеданного месторождения (Средний Урал) установлен водный редкоземельный фосфат кальция и тория - броккит, который относится к группе рабдофана (Ca, Th, REE)[PO] $]_{4} \mathrm{H}_{2} \mathrm{O}$. Это редкий для Урала минерал, до настоящей находки описывался в гранитных пегматитах Среднего и Южного Урала, а также в дайках метаплагиогранитов Баженовского офиолитового комплекса. Броккит был обнаружен в околорудных метасоматитах Сафьяновского медноколчеданного месторождения по кристаллолитокластическому туфу (туфопесчанику) кислого состава. Основная масса породы состоит из кварца, каолинита (серицита), карбонатов (доломит, Fе-магнезит) с редкими вкраплениями пирита. Броккит находится в доломит-кварцевом матриксе образца в сростках с РЗЭ-гояцитом - алюмофосфатом стронция. Для Сафьяновского медноколчеданного месторождения предполагается близко-одновременное образование глиноземистой ассоциации с рудной минеральной ассоциацией и редкоземельными минералами, в частности, РЗЭ-алюмофосфатами и фосфатами при падении температуры и изменении окислительно-восстановительных условий среды минералообразования.

Ключевые слова: броккит, гояцит, метасоматиты, Сафьяновское медноколчеданное месторождение, Средний Урал.

Работа выполнена в рамках темы государственного задания ИГГ УрО РАН (номер гос. регистрации ААА-АA18-118052590028-9).

\section{ЛИТЕРАТУРА}

1. Язева Р. Г., Молошаг В. П., Бочкарев В. В. Геология Сафьяновского колчеданного месторождения (Средний Урал). Екатеринбург: УрО $\mathrm{PAH}, 1992.70 \mathrm{C}$

2. Грабежев А. И., Молошаг В. П., Сотников В. И. Метасоматический ореол Сафьяновского Zn-Сu-колчеданного месторождения, Средний Урал // Петрология. 2001. № 3. С. 294-312.

3. Сорока Е. И., Молошаг В. П., Леонова Л. В., Галеев А. А. Новые данные по гидротермально-измененным породам Сафьяновского колчеданного месторождения (Средний Урал) // Ученые записки Казанского государственного университета. 2009. Кн. 1. Т. 151. С. 235247.

4. Сорока Е. И., Леонова Л. В., Притчин М. Е. РЗЭ-гойяцит в околорудных породах Сафьяновского медноколчеданного месторождения (Средний Урал, Россия) // Уральская минералогическая школа-2019: материалы молодеж. научн. конф. Екатеринбург: УГгУ, 2019. С. 160-162.

5. Молошаг В. П., Сорока Е. И., Филиппов В. Н. Алюмофосфрат стронция в породах Сафьяновского колчеданного месторождения (Средний Урал) // Теория, история, философрия и практика минералогии: материалы междунар. симпоз. Сыктывкар: Геопринт, 2006. С. 192-193. 6. Притчин М. Е., Сорока Е. И., Молошаг В. П., Замятин Д. А. Находки гойяцита в метасоматитах Сафьяновского медноколчеданного месторождения // Уральская минералогическая школа-2014: материалы молодеж. науч. конф. Екатеринбург: УГГУ, 2014. С. 213-216. 7. Попов В. А., Кобяшев Ю. С. Находки астрофиллита, броккита и моттрамита в Ильменских горах // Уральский минералогический сборник. Миасс: Ин-т минералогии УрО РАН, 1995. № 5. С. 190-196.

8. Губин В. А., Хиллер В. В. Акцессорный броккит из пегматитов северо-восточной окраины Адуйского гранитного массива (Средний Урал) // Вестник УрО РМО. 2012. № 9. С. 40-42.

9. Попова В. И., Губин В. А., Чурин Е. И., Котляров В. А., Хиллер В. В. Редкометалльная минерализация гранитных пегматитов Режевского района на Среднем Урале // Записки РМО. 2013. Ч. 142, № 1. С. 23-38.

10. Попова В. И., Чурин Е. И., Блинов И. А., Губин В. А. Фергусонит-(Ү) и продукты его изменения в гранитном пегматите жилы Береговой

\footnotetext{
\soroka@igg.uran.ru

https://orcid.org/0000-0003-1360-6274

"Ivleonova@yandex.ru
} 
Зенковского массива на Урале // Новые данные о минералах. 2012. Вып. 47. С. 47-55.

11. Ерохин Ю. В., Хиллер В. В. О находке броккита в дайках плагиогранита Баженовского офиолитового комплекса (Средний Урал) // Ежегодник-2017: труды ИГГ УрО РАН. 2018. Вып. 165. С. 183-185.

12. Ерохин Ю. В., Хиллер В. В., Иванов К. С. Раннесилурийский возраст даек плагиогранита из Баженовского офиолитового комплекса, Средний Урал (по данным Тh-U-Рb-датирования монацита) // Вестник ВГУ. Сер. «Геология». 2018. № 3. С. 17-21.

13. Сорока Е. И., Молошаг В. П., Леонова Л. В., Филиппов В. Н. РЗЭ-минерализация в околорудных породах Сафьяновского медноколчеданного месторождения (Средний Урал) // Десятые Всерос. науч. чтения памяти В. О. Полякова. Миасс: Ин-т минералогии УрО РАН, 2009. C. 30-35.

14. Deyell C. L., Rye R. O., Landis G. P., Bissig T. Alunite and the role of magmatic fluids in Tambo high-sulfidation deposit, EL Indio-Pascua belt, Chile // Chemical Geology. 2005. Vol. 215, № 1. P. 185-218. https://doi.org/10.1016/j.chemgeo.2004.06.038

15. Dill G. H. The geology of aluminium phosphates and sulphates of the alunite group minerals: a review // Earth Science Reviews. 2001. Vol. 53. P. 35-93. https://doi.org/10.1016/S0012-8252(00)00035-0

16. Сорока Е. И., Притчин М. Е., Лютоев В. П., Галахова О. Л. Магнезитовая минерализация околорудных пород Сафьяновского медноколчеданного месторождения (Средний Урал) // Записки РМО. 2016. № 2. С. 96-109.

Статья поступила в редакцию 19 мая 2020 года 